\title{
The health of Britain's Polish migrants: a suitable case for history taking and examination
}

In 2004 eight new countries (the A8) were admitted into the European Union (EU), allowing their citizens full rights of settlement and employment in the UK. Initial estimates by the Labour government were that between 5000 and 13000 people would migrate to the UK, which proved a gross underestimate. Although exact population data is difficult to obtain precisely because of free movement, it is estimated that at least 2 million have actually done so, around half this number from Poland alone. ${ }^{1}$ This migration has had a significant impact on both the UK and the migrants themselves, including their health. Little has been published about health issues affecting the Polish community, which begs the question: what does the piecemeal evidence so far suggest? In short, it is cause for concern.

Polish organisations are reporting high levels of suicide, depression, and poverty amongst migrant workers. ${ }^{2}$ Most worrying are unreleased figures from the Polish embassy indicating that a fifth of the 250 Poles who died in Britain in 2007 took their own lives. ${ }^{2}$ The emerging data has prompted MP Daniel Kawczynski, who is of Polish descent, to call upon the Polish government to improve support services for this population. ${ }^{2}$

The causes of these health outcomes are necessarily multifactorial and interlinked, although key determinants deserve particular consideration, mainly those relevant to psychological health. Bashir Qureshi has noted, anecdotally, that Eastern Europeans appear to have high rates of depression and somatisation disorder. ${ }^{3}$ A study from Sweden comparing rates of attempted suicide in immigrants from selected countries showed the risks in Polish men and women to be $42 \%$ and $95 \%$ higher respectively than in indigenous Swedes. ${ }^{4} \mathrm{~A}$ likely contributory factor in the Polish community is heavy alcohol intake, ${ }^{5}$ which may be both a cause and consequence of depression. Polish migrants also fare badly where smoking, the major preventable cause of illness, is concerned. A survey of Ireland's Polish population indicated that $61 \%$ of men and $47 \%$ of women smoke, compared with a $35 \%$ prevalence in 'home' Poles and $31 \%$ of indigenous Irish; ${ }^{6}$ the picture in the UK is likely to be similar.

Given the well-known association between deprivation and ill health, ${ }^{7}$ a significant factor with a negative impact on the health of migrants is relative deprivation. Poles are over-represented in occupations such as catering and construction, where poorly paid, hard physical work is the norm. ${ }^{2}$ Over-crowding in rented accommodation is rife, the migrants accepting relative poverty in the UK in order to try and save money with a view to sending it to families back home.

In addition, difficulties accessing health care have been noted, with high rates of presentation to emergency departments not only with trauma and acute illness, but for minor and chronic illness better suited to primary care. ${ }^{8}$ There has been a paucity of both research and service provision targeted at the healthcare needs of this population; exceptions such as the Barka project demonstrate their potential efficacy. ${ }^{5}$ Based in Hammersmith and Fulham, a London borough with a large established Polish community in addition to more recent migrants, it was a 6-month collaboration between the borough council, a Polish charity, and the Broadway Centre that worked with homeless migrant workers, who invariably had alcohol addiction, to refer them for treatment or to reconnect with their families.

The wider context in which the recent wave of Polish migration to the UK occurred is probably relevant. The UK government had, by not applying any caveats to citizens of A8 countries settling here (in contrast to France and Germany), always been, at least tacitly, in favour of substantial immigration. It also portrayed The UK's economic boom at the time to be rather more substantial than it actually was, making moving here appear a beguiling option. Yet the reality was rather different: a land of milk and honey for bankers, sports stars, and anyone deemed a celebrity, sure enough, but for most the boom was built on the fragile foundations of a credit-fuelled consumer spending spree. The consequences of this flawed approach has been a major factor in the downward trend in the economy, one consequence of which has been that a number of Poles have left the UK. In tandem with this the Polish economy has been expanding healthily.

Short-termism and materialism cannot paper over worrying social trends such as the sharp reduction in social mobility, ${ }^{9}$ a fact particularly noticeable among immigrants. Immigrant success stories from humble beginnings have been a heartening feature of the UK's landscape for generations. Many within the prosperous Jewish community are the descendants of tailors, while many feisty Irishmen who own construction firms started work in the trade as young men armed with no more than a shovel and a fierce work ethic; these are but two examples. For new migrants, however, the playing field appears much narrower, not least because the Holy Grail of corporate profit has spawned an economic structure demanding a flexible, transient, and ultimately disposable workforce, ${ }^{10}$ a structure the government is in no hurry to dismantle. Far from it; they have a notable tendency to genuflect to the requirements of big industry, as it has shown in other aspects of public policy such as the illconceived extension of licensing hours. ${ }^{11}$ The welcome afforded to Polish migrants appears to have patronising undertones, not only to the Polish community but also to the UK's sickness benefit claimants, the de facto long-term unemployed for who the government, by inference, seems to harbour no real ambition beyond the predictable, platitudinous rhetoric.

Meanwhile, irrespective of how many individuals return home, based on the sheer scale of recent migration, the Polish community will continue to be a substantial 
Strictly Doctoring

Health minister Ben Bradshaw has announced an official NHS website on which patients can 'post messages about their experiences of GPs' and rate their professional standards. ${ }^{1}$ Hoping that consumer feedback will 'improve standards through competition', the government is following the lead set by medical entrepreneur Neil Bacon of doctors.net who invited patients to comment on their doctors on his 'I want great care.com' website last summer (http://www.Iwantgreatcare.org). Although these populist initiatives have been condemned by the BMA and other authorities, they have much in common with the proposals for 're-licensing' of medical practitioners due to be introduced by the GMC later this year.

It seems that Bradshaw has been inspired by the contribution of Trip Advisor to the travel industry and Amazon to the book trade and believes that 'we need to do something similar for the modern generation in healthcare'. For its revalidation process the GMC has chosen a model closer to that followed by the television show Strictly Come Dancing, in which contestants are judged by a combination of studio experts and public voting (with predictably confusing results). ${ }^{1}$ This approach may provide good entertainment, but it seems unlikely to improve the quality of medical care.

In addition to maintaining an ever bulging folder about their practice, doctors seeking 're-licensing' will be required to provide positive 'feedback' from patients and colleagues. It is ironic that the doctor whose name is most closely associated with the drive to introduce new processes of revalidation - the late Harold Shipman - would have had little difficulty in demonstrating his high levels of performance.

Any GP would have been proud to include the Shipman Inquiry's comments on his professional standards in their personal development portfolio (if not in a frame on the waiting room wall):

'Shipman had the reputation in Hyde of being a good and caring doctor. He was held in very high regard by the overwhelming majority of his patients. $\mathrm{He}$ was also respected by fellow professionals. His patients appear to have regarded him as the best doctor in Hyde. His register was full and there always seems to have been a waiting list. Patients liked him for a variety of reasons. Many would say that he 'always had time' for them. His surgeries overran but no one minded because they understood his wish to take whatever time was necessary for each patient. He never hurried them out. He always had time for a few words of a personal nature. Elderly patients and their families were particularly grateful for his willingness to visit at home.'

Critics of the government's crass consumerist approach to health care have observed that Bradshaw's website is likely to encourage expressions of, on the one hand, anger and resentment, and on the other, gratitude and praise, perhaps justified, more likely not - and certainly of dubious value to potential patients.

The market has long been recognised as a threat to professional standards. In his celebrated study of doctors in the US, Paul Starr noted that 'the contradiction between professionalism and the rule of the market is long-standing and unavoidable'. ${ }^{3}$ Previously, doctors distinguished themselves from tradesmen and businessmen by claiming a commitment to a higher cause than vulgar commercial interests. Whereas the market ideal is that the consumer rules, the ideal of a profession 'calls for the sovereignty of its members' independent, authoritative judgement'. ${ }^{4}$ From this perspective, a quack is a practitioner who tries to please his customers rather than his colleagues.

Patients may be more likely to suffer harm from an incompetent GP than they are to become victims of another GP serial killer. They are more likely still to suffer the adverse consequences of the destruction of the autonomy of the medical profession and the corruption of doctor-patient relationships that results from the incursion of state and commercial forces.

\section{REFERENCES}

1. BBC News. Patients to rate GPs on website. http://news.bbc.co.uk/1/hi/health/7804125.stm (accessed 9 Jan 2009).

2. General Medical Council. Licensing and revalidation. http://www.gmc-uk.org/about/reform/index.asp (accessed 9 Jan 2009).

3. The Shipman inquiry. Professional reputation. http://www.the-shipman-

inquiry.org.uk/fr_page.asp?id=176 (accessed 9 Jan 2009).

4. Starr S. The social transformation of American medicine. New York: Basic Books, 1982.

DOI: 10.3399/bjgp09X407009 